\title{
Tatjana Verezubova
}

Białoruski Państwowy Uniwersytet Ekonomiczny w Mińsku

e-mail: verezubova@mail.ru

\section{KAPITALY BIALORUSKICH \\ ZAKŁADÓW UBEZPIECZENIOWYCH - ANALIZA STRUKTURY I PROBLEMY WYCENY*}

\section{CAPITAL OF BELARUS}

\section{INSURANCE ORGANIZATIONS -}

\section{STRUCTURE ANALYSIS AND EVALUATION PROBLEM}

DOI: 10.15611/pn.2017.484.19

JEL Classification: M41

\begin{abstract}
Streszczenie: Kapitał jako źródło finansowania stanowi istotną pozycję bilansową. Dla niektórych podmiotów prowadzących działalność w warunkach białoruskiego ustawodawstwa jego posiadanie wiąże się $\mathrm{z}$ wieloma problemami, dotyczącymi np. wyceny. W artykule dokonano analizy kapitałów białoruskich spółek ubezpieczeniowych. Celem artykułu było określenie podstawowych elementów kapitału oraz identyfikacja podstawowych problemów związanych z jego tworzeniem i wykorzystywaniem przez te podmioty w Republice Białorusi. Szczególną uwagę poświęcono problemom bieżącej i bilansowej wyceny kapitału, a także jego wystarczalności dla zachowania wypłacalności ubezpieczycieli. Analizą objęto również rezerwy ubezpieczeniowe, które stanowią szczególną, charakterystyczną dla tej grupy podmiotów pozycję pasywów. W artykule jako metody badawcze wykorzystano analizę i dedukcję. Przedmiotem analizy była literatura z dziedziny rachunkowości i akty prawne obowiązujące w tym zakresie na Białorusi.
\end{abstract}

Słowa kluczowe: kapitał, zakłady ubezpieczeniowe, kapitał podstawowy, rezerwy ubezpieczeniowe, zyski.

Summary: Capital as a source of financing occupies an important balance place . For some entities which are operating in accordance with Belarusian legislation, possession of it is associated with many problems, such as an assessment problem. Belarusian capital of insurance companies is analyzed in the article. The purpose of the article is to identify key elements of capital and the main problems associated with the creation and use of capital of these entities in the Republic of Belarus. Particular attention is paid to problems of current and balance evaluation of capital, as well as its sufficiency for maintaining the solvency of insurers. Also insurance reserves, which are a feature characteristic of this group of companies, and position

* Tłumaczenie dr Joanna Koczar, adiunkt w Katedrze Teorii Rachunkowości i Analizy Finansowej, Uniwersytet Ekonomiczny we Wrocławiu. 
of liabilities are analyzed. Analysis and deduction are used as research methods in the article. The subject of analysis is literature in the field of accounting and legal acts of Belarus.

Keywords: capital, insurance organizations, authorized capital, insurance reserves, profits.

\section{Wstęp}

Kapitał jest jedną z najważniejszych determinant stabilnego i ciągłego działania zakładów ubezpieczeniowych. Specyfika działalności w branży ubezpieczeń związana jest z przepływami dużych środków finansowych. W tej branży nie występują żadne surowce ani materiały - ich rolę odgrywają fundusze (środki pieniężne), które pochodzą ze składek ubezpieczeniowych płaconych przez ubezpieczających, a następnie są gromadzone przez ubezpieczycieli i przeznaczane na pokrycie przyszłych szkód ubezpieczeniowych. Wystarczający kapitał finansowy jest istotnym, wstępnym warunkiem realizacji przez zakłady ubezpieczeniowe swoich zobowiązań w przyszłości. Tymczasem pojęcie wypłacalności zawsze było i jest kontrowersyjne i w różny sposób szacowane przez naukowców i zarządzających zakładami ubezpieczeniowymi, co znacznie komplikuje możliwość rozwiązania problemów związanych ze stabilnością finansową ubezpieczycieli.

Celem artykułu było określenie podstawowych elementów kapitału oraz identyfikacja podstawowych problemów związanych z jego tworzeniem i wykorzystywaniem przez te podmioty w Republice Białorusi. Szczególną uwagę poświęcono problemom bieżącej i bilansowej wyceny kapitału, a także jego wystarczalności dla zachowania wypłacalności ubezpieczycieli. Analizą objęto również rezerwy ubezpieczeniowe, które stanowią szczególną, charakterystyczną dla tej grupy podmiotów pozycję pasywów. Jako metody badawcze wykorzystano analizę i dedukcję. Przedmiotem analizy była literatura z dziedziny rachunkowości i akty prawne obowiązujące w tym zakresie na Białorusi.

\section{Pojęcie kapitału w literaturze naukowej i aktach normatywnych Republiki Białorusi}

Kapitał jest jedną z najtrudniejszych do zinterpretowania kategorii ekonomicznych i księgowych. Praktycznie każda z teorii z dziedziny rachunkowości nadaje temu pojęciu własne znaczenie. Stwarza to warunki do powstawania wielu pokrewnych i jednocześnie niejednoznacznych definicji takich pojęć, jak: „kapitał firmy”, „kapitał właścicieli”, „kapitał pożyczony”, „kapitał zaangażowany”, „kapitał akcyjny”, „kapitał pozostały” i im podobnych.

W przestrzeni postradzieckiej rachunkowość zwykle traktuje kapitał zgodnie z podejściem zdefiniowanym przez ekonomistów z tradycyjnej szkoły, którzy uważają go za czynnik produkcji, czyli zasób, dzięki któremu organizacja uzyskuje 
przychód. Zgodnie z poglądami Adama Smitha kapitał jest jedną z dwóch części zasobów, tą, która ma wypracować przychód, a druga część ,jest przeznaczona do bezpośredniej konsumpcji”. Kapitał jest podzielony na trwały i obrotowy. Stosunek ich wartości zależy od charakteru gospodarki [Смит 2007].

Właśnie w takim podejściu należy szukać źródeł zdefiniowania kapitału jako przedmiotu rachunkowości. Jak zauważył W.F. Palii, narodziny rachunkowości były związane z pojawieniem się kapitalizmu, ale przedmiotem nauki rachunkowości jest kapitał. Pod tym pojęciem należy rozumieć zarówno wartość środków zainwestowanych w działalność gospodarczą, jak i proces przemieszczania kapitału oraz jego transformacji w procesie obiegu [Палий 2006]. Taka interpretacja kapitału dobrze odpowiada znanemu równaniu bilansowemu: Aktywa $=$ Pasywa.

Z kolei wartościowy pomiar kapitału był podstawą do powstania jednej z podstawowej zasad rachunkowości - zasady podwójnego zapisu, co jest słusznie podkreślane przez niektórych naukowców, w szczególności przez J. Sokolova [Соколов 2003, Соколов 2003, s. 44]. Definiując obiekty rachunkowości, Sokolov przez pojęcie kapitału rozumie „własne źródła środków pieniężnych”, które „składają się z funduszy, rezerw i zatrzymanych zysków".

W literaturze przedmiotu podkreśla się, że w krajach, które przeszły z gospodarki centralnie sterowanej na gospodarkę rynkową, nastąpiły znaczące zmiany w dziedzinie prawa bilansowego, dzięki którym system rachunkowości został dostosowany do nowych warunków gospodarczych [Koczar 2011, 2016]. Jednak proces wprowadzania zmian w wielu przypadkach jeszcze się nie zakończył, co powoduje, że przyjęte rozwiązania nie zawsze spełniają oczekiwania, a w niektórych przypadkach nadal brakuje np. definicji różnych pojęć. W obowiązującym obecnie na Białorusi krajowym ustawodawstwie z dziedziny rachunkowości nie określono np. do tej pory pojęcia kapitału. W ustawie „O rachunkowości i sprawozdawczości” Republiki Białorusi przyjęto, że w rachunkowości do wyceny aktywów, zobowiązań, kapitału własnego, przychodów i kosztów organizacji stosowane są:

- wartość początkowa - wartość określona dla danego składnika aktywów lub zobowiązań w chwili wprowadzenia go do ewidencji (dla celów rachunkowych);

- wartość bieżąca (zdyskontowana) - która stanowi obecną wartość przyszłych wpływów i rozchodów środków pieniężnych z danego składnika aktywów lub bieżącą wartość wykorzystania środków pieniężnych w przyszłości w celu realizacji zobowiązań;

- wartość przeszacowana - wartość składnika aktywów lub zobowiązania po przeszacowaniu;

- inne wartości wynikające z wyceny księgowej, określone przez ustawodawstwo Republiki Białorusi [Инструкция...].

Jednak należy podkreślić, że porządek stosowania wyceny księgowej opartej na wartości zdyskontowanej nie został do tej pory określony w przepisach prawa bilansowego Republiki Białorusi. W rzeczywistości ujęcie tego zapisu w prawie bilansowym stanowi formalne dostosowanie się do Międzynarodowych Standarów 
Sprawozdawczości Finansowej (MSSF). Został on wprowadzony po to, aby widoczne było zbliżenie białoruskiego prawa do rozwiązań zastosowanych w MSSF. Rozwiązanie to nie ma jednak realnej wartości metodologicznej.

Trzecia część bilansu, który obecnie - zgodnie z obowiązującymi krajowymi przepisami o rachunkowości - sporządzają białoruskie organizacje, nosi nazwę „kapitał własny". Pojęcie to odnosi się do równania bilansowego, z którego wynika, że aktywa - zobowiązania = kapitał. Dla zakładów ubezpieczeniowych, ze względu na specyfikę ich działalności, w pasywach bilansu przewidziano jeszcze jedną ważną pozycję, którą są „Rezerwy ubezpieczeniowe” (IV poz.).

\section{Struktura kapitału zakładów ubezpieczeniowych}

Działalność ubezpieczeniowa związana jest z przepływem środków finansowych, które w postaci składek ubezpieczeniowych są otrzymywane przez zakłady ubezpieczeniowe od ubezpieczających. Są one gromadzone w postaci specjalnych rezerw ubezpieczeniowych, przeznaczonych na zagwarantowanie w przyszłości wypłaty odszkodowań. Dlatego wraz ze zwykłymi składnikami kapitału, które występują w każdym podmiocie gospodarczym, ubezpieczyciele operują również rezerwami ubezpieczeniowymi. Dla tych rezerw w bilansie zakładu ubezpieczeń przewidziano oddzielne miejsce.

Konstrukcję kapitału w podmiocie prowadzącym działalność ubezpieczeniową przedstawiono na rysunku 1.

W kapitale zakładów ubezpieczeniowych Republiki Białorusi rezerwy ubezpieczeniowe stanowią ok. 50-60\%. Dynamika kapitału białoruskich ubezpieczycieli w ciągu ostatnich 5 lat została przedstawiona w tabeli 1.

Jak wynika z tabeli 1., jeżeli w 2012 r. kapitał własny białoruskich zakładów ubezpieczeniowych wynosił $80 \%$, a rezerwy ubezpieczeniowe $20 \%$, to w $2016 \mathrm{r}$. udział kapitału własnego zmniejszył się: proporcja wyniosła 57\% i 43\%, co wskazuje na wzrost zobowiązań ubezpieczycieli wobec ubezpieczających i rozszerzenie zakresu ich działalności. Udział kapitału zakładowego w kapitale własnym w analizowanym okresie wynosił średnio $80 \%$ i zmniejszył się nieznacznie pod koniec 2016 r., odzwierciedlając tym samym niedostatecznie wysoką rentowność działalności ubezpieczeniowej, ponieważ pozostała część kapitału własnego, zysk, utrzymała się na tym samym poziomie. Łączna kwota rezerw ubezpieczeniowych białoruskich zakładów ubezpieczeniowych na ubezpieczenia non-life wynosi $2 / 3$, a na ubezpieczenia na życie tylko $1 / 3$. Świadczy to o niedostatecznym rozwoju ubezpieczeń na życie, które mają charakter długotrwałego gromadzenia środków, a tym samym pełnią funkcję inwestycyjną. Przyjmując powyższe rozważania za punkt wyjścia, można zauważyć, że w analizowanym okresie, w latach 2012-2016, wartość kapitału własnego zmniejszyła się o $27 \%$, a rezerw ubezpieczeniowych wzrosła ponad dwukrotnie $(2,22)$. 


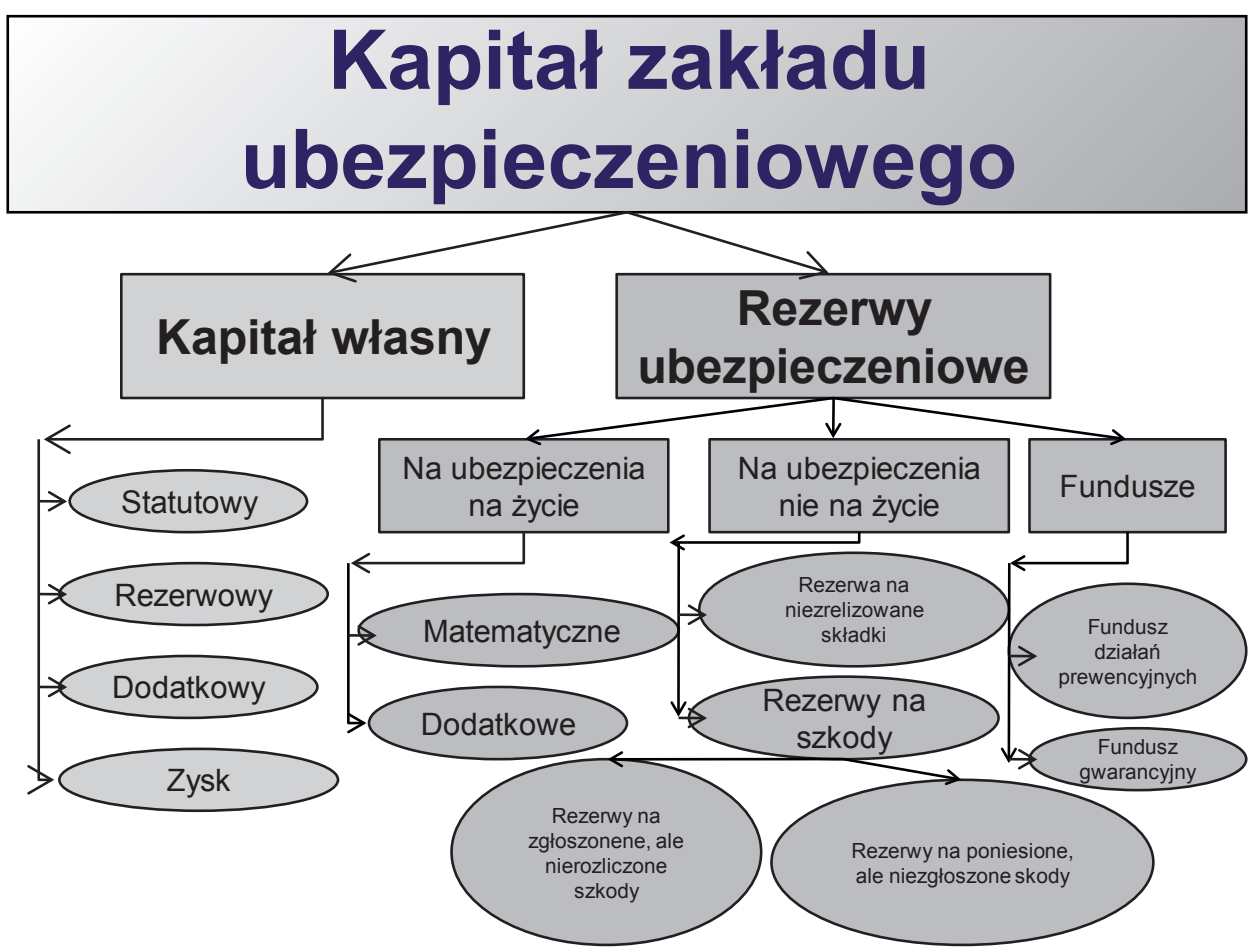

Rys. 1. Zasadnicza struktura kapitała zakładów ubezpieczeniowych

Źródło: opracowanie własne na podstawie ustawodawstwa obowiązującego na Białorusi.

Tabela 1. Dynamika poszczególnych pozycji kapitału białoruskich zakładów ubezpieczeniowych według stanu na koniec roku (w mln euro)

\begin{tabular}{|l|c|c|c|c|c|}
\hline \multicolumn{1}{|c|}{ Pozycja } & 2012 & 2013 & 2014 & 2015 & 2016 \\
\hline Kapitał własny & 957 & 902 & 844 & 669 & 696 \\
\hline - w tym kapitał podstawowy & 828 & 738 & 698 & 529 & 553 \\
\hline Rezerwy ubezpieczeniowe, razem & 236 & 359 & 489 & 429 & 524 \\
\hline W tym: & & & & & \\
\hline 1.1 ubezpieczenia non-life & 187 & 293 & 371 & 302 & 353 \\
\hline 1.2 ubezpieczenia life & 49 & 66 & 119 & 126 & 170 \\
\hline
\end{tabular}

Źródło: opracowanie własne na podstawie [www.minfin.gov.by].

Skrócony bilans jednego z największych na Białorusi państwowych zakładów ubezpieczeniowych Belgosstrakh przedstawiono w tabeli 2.

Jak wynika z tabeli 2., ponad połowę pasywów białoruskiego ubezpieczyciela stanowi kapitał własny, którego główną częścią jest kapitał zakładowy wniesiony 
Tabela 2. Wybrane pozycje bilansowe Belgosstrakha na dzień 1.01.2017 r. (w mln rubli białoruskich)

\begin{tabular}{|c|c|c|c|c|c|}
\hline \multicolumn{3}{|c|}{ Aktywa } & \multicolumn{3}{|l|}{ Pasywa } \\
\hline & 01.01 .2017 & 01.01 .2016 & & 01.01 .2017 & 01.01 .2016 \\
\hline $\begin{array}{l}\text { I. Aktywa } \\
\text { trwałe }\end{array}$ & 516 & 498 & $\begin{array}{l}\text { I. Kapitał własny, } \\
\text { w tym: } \\
\text { - } \text { kapitał zakładowy } \\
\text { - } \text { kapitał rezerwowy } \\
\text { - } \text { kapitał dodatkowy } \\
\text { - } \\
\text { niepodzielony zysk }\end{array}$ & $\begin{array}{r}582 \\
410 \\
2 \\
68 \\
102\end{array}$ & $\begin{array}{r}558 \\
402 \\
1 \\
65 \\
90\end{array}$ \\
\hline $\begin{array}{l}\text { II. Aktywa } \\
\text { obrotowe }\end{array}$ & 559 & 469 & $\begin{array}{l}\text { II. Rezerwy ubezpieczeniowe, } \\
\text { w tym: } \\
\text { - } \text { rezerwa na niezrealizowane } \\
\text { składki } \\
\text { - rezerwy na szkody } \\
\text { - inne rezerwy ubezpieczeniowe } \\
\text { - fundusz działań prewencyjnych } \\
\text { - fundusze gwarancyjne }\end{array}$ & $\begin{array}{r}161 \\
39 \\
222 \\
3 \\
1\end{array}$ & $\begin{array}{r}131 \\
34 \\
189 \\
2 \\
1\end{array}$ \\
\hline & & & III. Długoterminowe zobowiązania & 1 & 1 \\
\hline & & & $\begin{array}{l}\text { IV. Krótkoterminowe } \\
\text { zobowiązania }\end{array}$ & 65 & 52 \\
\hline $\begin{array}{l}\text { Suma } \\
\text { bilansowa }\end{array}$ & 1075 & 968 & Suma bilansowa & 1075 & 968 \\
\hline
\end{tabular}

Źródło: opracowanie własne na podstawie [http://bgs.by/files/files/bux\%20balans.pdf].

przez państwo (70\%). Rezerwy ubezpieczeniowe stanowią prawie 40\% sumy bilansowej. W związku z tym zasadniczą uwagę w następnej części niniejszego artykułu poświęcono problemom ich powstawania i wyceny w zakładach ubezpieczeniowych prowadzących działalność na białoruskim rynku.

\section{Problemy kształtowania i wyceny kapitału własnego oraz rezerw ubezpieczeniowych zakladów ubezpieczeń}

Obecnie zakłady ubezpieczeniowe prowadzące działalność na terenie Republiki Białorusi borykają się z wieloma problemami, które powstają w związku z kształtowaniem struktury i wyceną kapitału, którego suma jest gwarancją ich wypłacalności i realizacji zobowiązań wobec ubezpieczających. Do najważniejszych z nich należy obecnie zaliczyć:

1. Określenie zgodnie z obowiązującymi przepisami minimalnej wielkości kapitału zakładowego zakładu ubezpieczeniowego na poziomie $5 \mathrm{mln}$ euro.

2. Wskazanie, że gwarancją wypłacalności zakładów ubezpieczeniowych są rezerwy ubezpieczeniowe, dostateczny poziom kapitału własnego oraz system reasekuracji. 
Pierwszy problem związany jest z określeniem minimalnej wysokości kapitału zakładowego na poziomie $5 \mathrm{mln}$ euro. $\mathrm{W}$ związku z tym, że kurs euro $\mathrm{w}$ ciągu ostatnich pięciu lat wzrósł prawie dwukrotnie (z 1,134 pkt w dniu 1.01.2012 r. do 2,045 pkt w dniu 1.01.2017 r.), zakłady ubezpieczeniowe w analizowanym okresie stale borykają się z koniecznością podwyższenia kapitału zakładowego. Problem ten zaostrza się jeszcze bardziej w związku z tym, że zgodnie z prawem bilansowym kapitał zakładowy jest wyceniany w białoruskich rublach, nawet jeżeli faktycznie udziały zostały przez założycieli wniesione w euro lub innej walucie obcej. W konsekwencji wartość tego kapitału nie rośnie wraz ze wzrostem oficjalnego kursu danej waluty. Obecnie kurs euro ma tendencję spadkową, a więc zakłady ubezpieczeniowe, które tworzyły kapitał podstawowy w euro, mają inny problem - ujemne różnice kursowe prowadzą do niższych zysków, a nawet strat. Jednocześnie w takich instytucjach finansowych, jak białoruskie banki, najbliższych ze względu na specyfikę swojej działalności zakładom ubezpieczeniowym, minimalną wartość funduszu zakładowego prawo określa w walucie krajowej. Byłoby wskazane ustanowienie minimalnej wartości kapitału zakładowego dla ubezpieczycieli również w białoruskich rublach oraz umożliwienie przeszacowywania wartości wniesionych przez założycieli w walucie obcej wkładów, zgodnie ze zmianą oficjalnego kursu tej waluty.

Jeżeli chodzi o drugi ze wskazanych problemów, to wielkość rezerw ubezpieczeniowych powinna być adekwatna do odpowiedzialności, jaką bierze na siebie ubezpieczyciel. Ze względu na fakt, że wzrost rezerw ubezpieczeniowych oznacza zmniejszenie wyniku finansowego, i odwrotnie, ich redukcja przyczynia się do wzrostu zysków, państwo reguluje ich tworzenie zarówno z punktu widzenia zagwarantowania wypłat na rzecz ubezpieczających, jak i podwyższenia dochodów budżetowych. W Republice Białorusi regulacje te ujęte są w specjalnej instrukcji [Инструкиия...], zgodnie z którą zakłady ubezpieczeniowe muszą tworzyć rezerwy na niezrealizowane wpłaty i dwie rezerwy na straty, które wynikają ze zgłoszonych, ale nierozliczonych szkód, oraz na straty wynikające ze szkód poniesionych, ale niezgłoszonych (rezerwy te są widoczne na rys. 1). Pierwsze z nich są przeznaczone do zabezpieczenia środków na szkody, które mogłyby wyniknąć ze zdarzeń, jakie jeszcze się nie wystąpiły, a dwie kolejne generują środki na pokrycie szkód, które już wystąpiły, ale nie zostały za nie jeszcze wypłacone odszkodowania.

W światowej praktyce istnieje wiele metod wyceny rezerw przeznaczonych na pokrycie szkód. Większość z nich opiera się na przewidywaniu występowania wypłat na pokrycie szkód w czasie na podstawie tego, jak rozkładały się wypłaty w poprzednich okresach. Istota tych metod tkwi w tym, by ukształtowany w przeszłości, między jednym a drugim okresem, trend wypłat odszkodowań z tytułu szkód przełożyć na przyszłe okresy sprawozdawcze. Do takich sposobów obliczania rezerw przeznaczonych na pokrycie szkód zaliczana jest m.in. metoda trójkątów, technika Chain-Ladder, metoda góry lodowej czy metoda Bornhuetter- Fergusona oraz wiele innych. W metodach tych bierze się pod uwagę wzajemne oddziaływanie procesów związanych ze szkodami, które wystąpiły i z tytułu których zostały wypłacone od- 
szkodowania. Drugi aspekt stosowania tych metod stanowi wykorzystywanie informacji o szkodach pokrytych odszkodowaniami na dzień bilansowy. Ustawodawstwo wielu krajów przewiduje włączanie do sumy rezerw również marży, w celu zapewnienia niezawodności wypłat, która w strukturze taryfikatora stawek jest odpowiednikiem nadwyżki ryzyka [Руденко 2007]. Należy zauważyć, że wszystkie metody wyceny rezerw na szkody noszą probabilistyczny charakter, ponieważ istnieje niepewność co do samego faktu wystąpienia zdarzenia ubezpieczeniowego, jak i niepewność co do czasu jego wystąpienia oraz faktycznej wielkości szkody.

Wyniki badań audytorskich, w których uczestniczyła autorka, pokazują, że na podstawie obowiązujących przepisów Ministerstwa Finansów Republiki Białorusi jest praktycznie niemożliwe prawidłowe obliczenie rezerw na zgłoszone szkody.

Zgodnie z par. 22 białoruskiej Instrukcji [Инструкция...] jako podstawę do obliczenia wartości rezerw na zgłoszone, ale nierozliczone szkody należy zastosować wielkość występujących na dzień bilansowy zobowiązań ubezpieczyciela, podlegających zapłacie w związku z wystąpieniem zdarzeń, o których ubezpieczyciel, zgodnie z przepisami lub obowiązującą umową, został poinformowany przez ubezpieczonych. Jeżeli podlegająca, zgodnie z zawartą umową, ubezpieczeniu szkoda została zgłoszona, ale nie została oszacowana wielkość wypłaty, jaką będzie musiał zrealizować ubezpieczyciel, należy w celu oszacowania rezerwy przyjąć maksymalną możliwą wysokość odszkodowania nieprzewyższającą sumy ubezpieczenia. Po otrzymaniu dokumentów potwierdzających wysokość szkody rezerwy koryguje się zgodnie z tymi dokumentami. Jednak akty normatywne nie określają sposobu obliczania maksymalnej kwoty szkody. W zasadzie może to być suma ubezpieczenia wynikająca $\mathrm{z}$ umowy. Jednak należy podkreślić, że np. szkoda w postaci rysy na przedniej szybie samochodu ma wartość 800 białoruskich rubli. W takiej sytuacji niecelowe byłby tworzenie rezerwy o wartości 400 tys. białoruskich rubli, czyli w wysokości sumy ubezpieczenia. Zwłaszcza że zawyżenie odpisów na rezerwy ubezpieczeniowe prowadzi do zaniżenia podatku dochodowego od osób prawnych, co skutkuje sankcjami karno-skarbowymi, a zaniżenie z kolei pociąga za sobą dotkliwe sankcje administracyjne.

W sytuacji gdy na dzień tworzenia rezerwy wysokość szkody nie została ustalona, byłoby wskazane, aby wewnętrznym dokumentem określić i uzasadnić maksymalną możliwą kwotę odszkodowania. Naszym zdaniem może ona zostać określona poprzez:

- określenie przez ubezpieczającego wartości poniesionej szkody;

- ustalenie średniej wysokości wypłat z tytułu szkód, które powstały w samochodach w ciągu ostatnich dwóch lub czterech poprzedzających kwartałów;

- wykonanie aktuarialnych obliczeń opartych na teorii prawdopodobieństwa i statystyki matematycznej.

W ostatnim przypadku konieczne jest zwrócenie się do Ministerstwa Finansów Białorusi w celu uzgodnienia wykorzystania metod aktuarialnych. 
Aby właściwie wycenić rezerwy ubezpieczeniowe, proponuje się również wykorzystanie metod stochastycznych, których zastosowanie pozwala nie tylko na prostą wycenę rezerwy, lecz także na identyfikację granic przedziału ufności, który określa istotę rezerwy $\mathrm{z}$ zadanym prawdopodobieństwem. Założenie, że występowanie szkód w przyszłości będzie miało taki sam charakter, pozwala na prognozowanie ich występowania z wykorzystaniem VaR (Value-at-Risk) do oceny poziomu strategicznego ryzyka finansowego.

\section{Zakończenie}

Na podstawie przeprowadzonych badań można stwierdzić, że większą część kapitału zakładów ubezpieczeniowych stanowi kapitał własny oraz rezerwy ubezpieczeniowe. Ich wycena w sprawozdaniu finansowym ma ogromne znaczenie zwłaszcza dla jednej z zewnętrznych grup odbiorców informacji sprawozdawczej - ubezpieczających, którzy podejmują w danym momencie decyzję o wyborze ubezpieczyciela. Dlatego wielkość ta powinna być adekwatna w stosunku do realnej wartości kapitału towarzystwa ubezpieczeniowego, która gwarantuje stabilność finansową i wypłacalność zakładu ubezpieczeniowego. Istotnym problemem jest określenie wystarczającej wielkości kapitału ubezpieczyciela, która na całym świecie jest szacowana za pomocą analizy ryzyka. W związku z tym dla białoruskich zakładów ubezpieczeniowych bardzo ważne są doświadczenia związane ze stosowaniem przyjętego w 2016 r. w Unii Europejskiej systemu kontroli wypłacalności Solvency II. Analiza międzynarodowych doświadczeń w tym zakresie pozwoli przedstawić użytkownikom sprawozdań finansowych zakładów ubezpieczeniowych bardziej wiarygodne informacje, na których podstawie możliwe jest podejmowanie efektywnych decyzji zarządczych.

\section{Literatura}

Инструкция о порядке и условиях образования страховых резервов страховых организаций, утв. Постановлением Министерства финансов Республики Беларусь от 17.12.2007 № 188 (ред. от 29.09.2016).

Koczar J., 2011, Rosyjskie prawo bilansowe a identyfikacja, pomiar i wycena wartości niematerialnych, [w:] Cebrowska T., Dotkuś W. (red.), Wartości niematerialne i prawne - ujmowanie i prezentacja, Prace Naukowe Uniwersytetu Ekonomicznego we Wrocławiu, nr 190, Wydawnictwo Uniwersytetu Ekonomicznego we Wrocławiu, Wrocław, s. 133-147.

Koczar J., 2016, Aktywa finansowe ,źle obecne” w rosyjskiej rachunkowości, Prace Naukowe Uniwersytetu Ekonomicznego we Wrocławiu, nr 445, Wydawnictwo Uniwersytetu Ekonomicznego we Wrocławiu, Wrocław.

Палий В.Ф., 2006, О предмете бухгалтерского учета // Бухгалтерский учет, № 5, s. 55-58.

Руденко А.В., 2007, Метод расчета РПНУ на базе статистики произошедиих и оплаченных убытков. Страховое дело, № 8, s. 29-35. 
Смит А., 2007, Исследование о природе и причинах богатства народов, Эксмо, Серия: Антология экономической мысли.

Соколов Я.В., Соколов В.Я., 2003, История бухгалтерского учета, Финансы и Статистика, Moskwa.

\section{Źródła internetowe}

www.minfin.gov.by (29.05.2017).

http://bgs.by/files/files/bux\%20balans.pdf (29.05.2017). 